This is an electronic reprint of the original article. This reprint may differ from the original in pagination and typographic detail.

Author(s): Silvasti, Tiina; Hänninen, Sakari

Title: Giving up Farming as a Precarious Decision

Year: $\quad 2015$

Version:

Please cite the original version:

Silvasti, T., \& Hänninen, S. (2015). Giving up Farming as a Precarious Decision. In D.

D. Porta, S. Hänninen, M. Siisiäinen, \& T. Silvasti (Eds.), The New Social Division :

Making and Unmaking Precariousness (pp. 159-176). Palgrave Macmillan. Palgrave

Studies in European Political Sociology. https://doi.org/10.1057/9781137509352_9

All material supplied via JYX is protected by copyright and other intellectual property rights, and duplication or sale of all or part of any of the repository collections is not permitted, except that material may be duplicated by you for your research use or educational purposes in electronic or print form. You must obtain permission for any other use. Electronic or print copies may not be offered, whether for sale or otherwise to anyone who is not an authorised user. 


\section{Giving up farming as a precarious decision}

Tiina Silvasti \& Sakari Hänninen

\section{Introduction}

'Precarity' is a novel noun that is widely recognized and applied in timely political discourses and socioeconomic diagnoses of the present. It refers to fixed-term, temporary, low-paid, insecure, unpredictable, and often risky work. The occupational position of precarious people has been characterized as flexible or flexploitative, informal, casual, intermittent, non-standard, exceptional, often outsourced or subcontracted. 'Precarity' is typically seen to characterize young people, women, immigrants, and service sector workers; but particular segments of creative and immaterial 'new labour' are also identified with the 'precariat'. However, in spite of all these groupings, lists, and clusters, the 'precariat' remains a contestable and polyvalent term, giving rise and reason to endless definitional debates and classificatory clashes.

It is obviously more appropriate to talk about precariousness, precarization, and precarity than about a 'precariat'. In this way, 'precarity' might be conceived as an outcome of precarization. In order to get a better hold on this event of precarization, it is necessary to recognize the fragmentary and fractal character of this process. It may be better to talk about 'precarizations' in the plural. Besides, precarization may not be such a new phenomenon as is typically depicted, and it may also take place in socioeconomic folds in which it has been least expected or recognized by critically inspired spectators.

Precarization and precariousness are descended from pre caritas, and this descent is, here, illustrative. On the one hand, precarization expresses a process before (pre) the coming event and, 
thus, deals with individual and collective expectations and previsions connected with the structuration of opportunities. On the other hand, precarization is crucially concerned with the ways and means in which virtual 'high values' such as love (caritas) are actualized, and here, the crucial classical opposition could still be drawn between self-love (eros), rightly understood as self-interest, and mutually binding humble and even self-sacrificing love (agape) leading to solidarity (Nygren, 1936). It should be no wonder, then, that the ultimate issue of precarization, and the pertinent research question, address recognition (Honneth, 1996), and not just some narrowly conceived labour market position.

In spite of constant structural changes in agriculture leading to a weak labour market position for small-scale farmers, the farming population in the developed countries is hardly ever described as precarious, unless referring to migrant workers. There are, however, multiple groups of people in agriculture whose vulnerable situations could be examined in the frame of precarization. In this chapter the problem of precarization and precariousness will be examined in connection to the structural change in Finnish agriculture.

The event of precarization in agriculture will be dealt with in processual terms by trying to answer particular questions that convey the mobile, molecular, and fragile character of the phenomenon. This is done against the personal experiences of those people giving up farming due to this structural break. It is asked why, where, and how precarization starts and becomes likely to be perpetual. Does anybody intervene politically in this process from the outside, or is it just left to run its course under the principle that winner takes all? What kind of experiences behind decisions taken define precariousness during a structural upheaval in the economy? What are the decisive factors or functions that actually, if not ultimately, make human situations and events precarious? Finally, it will be asked and analysed how precarization in the context of drastic structural change in 
agriculture has been governmentally rationalized.

The empirical starting point for this study is composed of 16 deep interviews conducted in 2006-07 with ex-farmers who gave up agriculture in 1995 or after. These interviewees were picked up as a sample of a survey administered in 2005. It consists of farmers born in 1950 or after, so that they have at least ten more years of working life left after shutting down the farm. Those farmers who would soon have retired from farming were excluded from the sample. According to the survey, the most important reasons to give up farming were economic and family related. The selection of persons for the deep interviews was guided by this result (see Laitalainen et al., 2008).

\section{The change in the socio-economic position of farmers after 1995}

Finland joined the European Union in 1995. At the same time, the national agricultural policy was transferred under the Common Agricultural Policy (CAP). In spite of the subsidies offered for the transition period, the operational environment of agriculture changed dramatically overnight. As a consequence, between 1995 and 2007, the number of farms and farmers in Finland declined by more than one third; there seems to be no remarkable change in this development ever since. In 2006, there were 68,000 active farms left in Finland. By 2014, the number decreased to 5,000. Between 1995 and 2013, again, the number of employed persons in agriculture declined from 141,000 to 76,000 (Agrifood Research Finland, 2014, p.90).

After Finland joined the EU, producer prices in agriculture were immediately cut by half, on average. Prices of production inputs also decreased, but this reduction could not compensate for the cuts in producer prices. Hence, different kinds of subsidies have been allocated, following the policy guidelines of the CAP, especially to bigger farms, to cover the gap between the costs of 
inputs and outputs. The share of subsidies in farmers' income has, generally speaking, risen during the EU membership. In recent years, however, direct support payments have decreased. In 2011, they were 37 per cent on average and 50 per cent for cereal, sheep, and beef cattle farms. There has also been a remarkable polarization within agriculture. Production is becoming increasingly centralized, both regionally and at the farm level. The structural change has been strongest in the remote countryside of northern and eastern Finland, where dairy husbandry has been the dominant farming sector. Due to other economic activities and migration, agriculture is also concentrated in the cereal cultivation areas of southern and western Finland (Agrifood Research Finland, 2013, p.83).

Constant pressure towards the profession and livelihood as well as uncertainty about the future often manifest as weakening welfare and health at the individual level. The remarkably lower ability to work is explained by four factors: Farm work is physically hard and exhausting; farmers work longer days than do workers on average; farmers are older than workers on average; and there is continuous uncertainty and doubt about the CAP and its reforms (Helakorpi et al., 2004, pp.436).

In contrast to the earlier national agricultural policy based on the Nordic welfare state rationality, Common Agricultural Policy does not include any special social dimension. The farming subsidies of the national agricultural policy had been, since the 1960s, articulated in reference to the developing welfare state. The state took responsibility for subsidizing farming, partly in order to level income disparities. The agricultural sector was included in the social dimension of the welfare state from the beginning. Regional subsidies and acreage supplements were clearly social by nature. The farm income system based on law was guided by the principle that farmers' income should evolve in accordance with that of other population groups. Along with the EU membership, farmers 
lost their position as an established interest group in general income policy setting (Granberg, 1996) - despite the fact that along with the EU membership the income equalization policy became past history, and no particular welfare subsidies were allocated to farmers.

In the rhetoric of progress, including rural policy, the development of rural areas is usually connected with the so-called new rural livelihoods such as remote work, tourism, sub-contracting, or bio-fuel production. Traditional livelihoods, like production of food and fibre, are not easily included in this basket. Sometimes this rhetoric even seems to present primary production as an obvious obstacle for streamlining development towards a post-modern and economically viable countryside (van der Ploeg, 2000).

The significance of agriculture to regional economics differs greatly in different parts of Finland. It is smallest in the Uusimaa region and largest in the eastern and northern parts of the country. In these areas, farming also supports the demand for many other commodities and services. According to the regional accounting (Tilastokeskus, 2004b), the dominance of agriculture in the economic structure of a region indicates a low standard of living. Regions that were most dependent on agriculture and forestry were not able to keep up with the economic growth even before the present recession. There have been more farm closures in these regions than in Finland as a whole (Tilastokeskus, 2003, p.20).

The cuts in public expenditures have also been heavily focussed on these regions, since the proportion of employment in the public sector has been especially high here (Valtioneuvosto, 2000a, p.6) It is known that during 1990-2007, more than 90,000 jobs (about half of all jobs in business) were lost in agriculture. High regional unemployment compels people to move out of these regions in great numbers. 


\section{Experiences of persons giving up farming}

In order to get a more tangible picture of the events and experiences of giving up farming, four illustrative cases will be briefly described. These cases are selected from the multifaceted interview data due to their particular relevance, illustrative of many other interviews as well. Each of them highlights a specific critical dimension in which the process of giving up acquires a characteristic pattern. Since the motives for giving up are always plural, this kind of emphasis is meant to capture in each case either the most decisive reason for giving up - which is mostly economic - or the most significant attribute of giving up.

Tapio and Valma's story is an account of a quite small but relatively old family farm dating back to the nineteenth century, which Tapio took over in the 1970s at barely twenty years old. A few years after that, he married a woman of farming background. They had children and were both engaged in work on their family farm, which was expanded by renting more land. The economic difficulties of the farm had already begun before the 1990s, when Tapio realized that the estate was too small and old as well as indebted, and that farming could not be successfully continued there without significant investments in new land, buildings, and machines. In circumstances of great uncertainty about future prospects of agriculture and the existing financial burdens, this was totally out of the question. The definite task at hand for Tapio and his family was to take care of the debts, which ended up overwhelming him in spite of the fact that the bank was, in his case, unusually flexible certainly not the experience of many other interviewees. When the difficulties accumulated rapidly in the 1990s, partly due to the loss of contractor work outside agriculture, Tapio decided not to tell his wife about the piling up of unpaid bills. Eventually, Tapio was taken ill by a severe depression, which lasted for years. During this time, from the late 1980s until the late 1990s, the farming was 
reduced little by little, first by giving up the milking cows but keeping the beef cattle. This opened up the possibility for Tapio’s wife Valma to work outside the farm by the early 1990s. However, the final decision to give up farming altogether was only made after ten years of severe struggling with various hardships, adversities, and setbacks.

When the final decision to give up farming was made, the family experienced it as a great relief. Even though Tapio could pay off a substantial amount of his debts with the money acquired from the selling of the land and animals, his family's economic situation remained very weak and vulnerable. The advantage in his situation was that they did not have to leave or sell their house, and that he was again healthy enough to look for a job in the labour market. With such a job in mind, he started negotiations with the employment authorities. But it was not so easy for an ex-farmer to go to the local employment agency, as Valma emphasizes at the outset:

Valma: Now it's that a farmer cannot go to the employment agency, just that.

Tapio: I thought that I'll go anyway and see what happens. Then I had to bring with me paper after paper and do everything ... nothing much seemed to come out of that, though ultimately I got the basic support to live on relief, as I said that I would have nothing else.

Valma: They were prone to claim, that he can employ himself in his own farm, when there were farmland. But all the land had been rented to be later purchased.

After having been shunted around for over a year (between various clauses and agencies), Tapio finally got a decision by the authorities as a precedent that recognized him as eligible for basic income assistance. At the same time, he was given and urged to take an opportunity to participate in 
a retraining course. In this way, Tapio was led to start a patisserie business, which seemed to work well at the beginning. However, he was not able to meet the demand despite trying his utmost with help from his wife and even his children. The family had to give up the practically handmade production in three shifts, as his wife became totally exhausted, the children moved away, and Tapio himself was tormented by a nerve injury and the threat of burnout. Tapio was again compelled to contact the employment authorities, since he had lost his livelihood for the second time in five years. This second visit to the employment agency turned out to be as complicated and forbidding as the first. This time, the employment authorities did not decline his right to basic security on the grounds that he could continue to be an entrepreneur - a typical counter-argument in many such cases - but because of the income of his spouse Valma. They suggested that Tapio should wait for a decision until the law is rewritten on this relation as soon expected which they considered to be a better alternative than to apply for a pension. At the time of the interview, Tapio had been without any income for nearly a year.

The crucial reason for Tapio and Valma to give up farming, and small-scale patisserie production, was undoubtedly economic - or, more specifically, the dominant logic of markets which they just could not meet with the resources available. They could only rely on themselves, the family, without any support from the surrounding community. The final decision to give up was also definitely influenced by the government policies adopted in the 1990s, which were basically designed according to this market logic. However, the difficulty in making this 'overdue decision' can only be explained by Tapio and Valma's strong devotion to the ideal of the continuity of the family farm. The nucleus of this devotion situates in the farm estate as a dwelling place. The real wound in Tapio and Valma's story is that the name of their farm was seized and taken over without permission and used to name the new residential area that was constructed right next to them. 
Jari's story is described by him, but it also involves his family. Jari was born in the mid-1960s to a farming family; at the age of 22, he took over by succession the family farm, which dated back to the sixteenth century. The reason for doing so was simple:

Tradition. I was already leaving for an assignment abroad at 18, as I had done my service in the army, when at home it was voiced that I cannot do so since I was so needed there and I was naturally so grown to the idea from childhood.

Jari was the youngest son who could not avoid it that the succession broke his relations with his older brothers as he just abode the wishes of his parents who thought that the continuity of the family farm went above all else (Silvasti, 2003a; 2003b). Due to this succession, Jari took over the already indebted home-farm, with 25 hectares of field and 30 hectares of forest largely based on domestic animal production. At the beginning, everything seemed to proceed well, so that the turnover was growing and he could amortize his loans. However, all that changed in the 1990s when Finland ran into a bank crisis; his loans were managed by a savings bank, which was at the very centre of the crisis.

It was only natural for the banks in crisis to ask the state to guarantee and subsidize them with taxpayers' money, as well as placing responsibility with their own clients to carry the consequences for the managers' reckless risk-taking and mistakes. Jari explains that in these circumstances,

I was asked to come to the bank and I was informed, by the manager, that this great Savings bank's, that that ... the state has opened its pocket and you will be transferred there. After that all faucets were closed for me and it was that. When I asked reasons for doing so, I was told that the banks do not have to give any reasons for their clients. 
In other words, when the state promised to take over any of the risky loans held by the banks in crisis, this gave their managers and boards totally free hands to operate, manipulate, and even swindle at will with their clients’ promissory notes and mortgaged assets. Jari continues:

They did not have to give reasons for that. I quite well know that behind all this there were ... it was no secret to me ... there were some members of the board who wanted to have that land of mine.

Jari’s elderly parents had already retired and moved away, and his girlfriend lived in a nearby town - which Jari thought for the best as his situation became tighter and tighter. Jari knew that, even though his home-farm was indebted, it was basically in good condition. However, the bank refused all negotiations and without money, Jari could not continue its operations but had to sell what he could on the farm. He sums up:

When you are refused funding, so you start making your own decisions. One mistake leads to another, then to the third, and to the fourth, when you have to act in a hurry.

In this way misfortunes started to accumulate, but the bank refused to do anything for him. Therefore, in 1994 Jari closed, for the last time, the door of the farm which had belonged to his family for many centuries. Ultimately, the farm had to be sold at an absurdly low price. Although this deal was dictated from the outside, the authorities still charged Jari a tax of tens of thousands of euros - even though all the returns from the deal had already gone to the debtors.

Being in debt is the true story of Jari's agony and anxiety of precarity. When Jari left the home- 
farm, it was practically the property of the bank: he had no income, and he was marked as being over-indebted. For the last four years before leaving everything behind and moving to live with his girlfriend and future wife, Jari stayed on to keep the farm in shape, but he really did not live there. Two years after leaving the farm, Jari went to work abroad, thanks to the vocational schooling he had acquired after graduating from high school. He would have liked to leave the 'system' for good, but his wife was against leaving Finland.

Back in Finland, Jari tried to apply for a housing allowance but was denied due to his unfinished livery of possessions. He also made a serious effort to enter a debt consolidation scheme, as he had to pay interest of up to 25 per cent for his loans; but the bank did not support his application as promised, and the public authorities made no effort to help him. On the contrary! Jari’s story makes crystal clear that the conduct of banks and public authorities went to absurdities: it was not only indifferent but actually cruel to Jari and his family, especially in the case of particular individuals such as the bank manager and the bailiff.

There were not many alternatives left for Jari and his family (with children) in his precarious situation. Since he could only trust in himself and the family, Jari became an entrepreneur and started a business - which he had to register in his wife's name due to his own insolvency, causing him constant fear that he was risking his wife and family. However, in this way they were able to manage their life better and better each year, especially after Jari was approved, at the advice of a private counsellor, to the debt consolidation scheme. All of this took 14 years of his life, and only a little less of his wife's. About this process of precarization, Jari makes the simple conclusion:

I would say that a few persons had the power to take 14 years of my life. ... I am not bitter about that these years were taken. And surely not that the home-farm went, that's just 
matter. But that they took my life. That is what I am bitter about.

In turning to Markku's story, we are dealing with a more successful process of giving up than is the case with Tapio and Valma, or with Jari. Markku was born in the 1960s as the only son and inheritor of a family farm whose lineage also reaches back 300-400 years. When his father retired in the late 1980s, he took over the relatively small farm, as was expected by long tradition - even though farming was not the occupation of his dreams. He had, however, acquired an education fit for farming. Since this farm was also situated in a rural region near the city, there opened up a good enough opportunity to combine farming with working outside the farm in the late 1980s and early 1990s. At this time, farming not only became a part-time job for him but occupied him especially during evenings, weekends, and holidays; his schedule became tighter than ever, since there were also small children in his family. In these circumstances, Markku started seriously to think about alternatives.

After twenty years of farming, Markku decided to rent his farmland and completely give up even part-time farming. Markku himself emphasizes that it was Finland's decision to join the EU, along with a change in the agricultural policy (practice), that really made him take this step:

The final impulse to give up was really the introduction of these EU-regulations. When everything changed and anything at hand had to be scrutinized more and more punctiliously. It was not unfeasible for me to fill all these forms, but I just got tired of doing so. When you were constantly asked to be trained anew or compelled to participate in some course, although it all amounted to what was there previously. ... In the beginning of the 1990s, I must say, the income from agriculture was about half of all my earnings. In the last years it was about 30 percent of my total income. So I asked myself if there is any sense in this 
farming any more, that you have dirty hands and have to breathe the same dust.

In giving up farming, Markku and his family did not have to give up their dwelling place, since he managed the change by renting the farmland and selling a plot for a detached house. The process of giving up actually proceeded very smoothly since there were no thorny debts to burden his personal economy, and the farm was situated in a rural region near the city where he was already regularly employed. However, he makes it clear that the income on which he and his family now have to manage is clearly smaller than it was before giving up. He adds, though, that they are accustomed to living very modestly and that this way of living corresponds with his critical outlook: that farming has lost its character and has been taken over by the ideology of competition, consumption, and growth, which is made to rotate on credit. Markku's reluctance to live and run the farm on credit is reminiscent of the orientation of the yeoman-type farmer outlined in the American research literature (Salamon, 1992). It is characteristic of this kind of moderate management of the farm, in contrast with the entrepreneurial farming style, that it tends to minimize both gains and losses, since it avoids risky investments on credit. As a result, Markku did not have to hesitate in the giving-up decision but could count on the principle that 'time is money'. In this way, he can also wait and see if any of his children might like to redeem and take up, in the future, the family farm.

If Markku was a yeoman-type farmer, then Kai really tried out what it means to be an agricultural entrepreneur on credit (Salamon, 1992). Born in the 1950s, Kai was the only son of a farming family with many children. Besides farming, his father also had another job, business in fact. Kai was interested in farming and married quite young. His wife also had a farming background. The young couple bought a small farm in their home district and came along sufficiently well, since even small scale pig breeding was then (in the 1970s) worthwhile, and since he could work fulltime outside the farm while his wife worked on the farm and took care of the children. 
After five years, they decided to buy a farm estate from another region, mainly a large pig house in addition to farmland and some forest. This estate was acquired on credit so that they were deeply in debt. They managed quite well the first five years, since they did not initially have to service the debt for the state loan, which was half of the total sum. After that, problems started to accumulate. In about 1992, they had to start negotiations with the bank in order to somehow manage until the mid-1990s. However, once Finland joined the EU, the agricultural income from Kai’s pig breeding collapsed and there were no means available to balance his farming business. Since he could not prolong the repayment period of his debts, he had to take new loan from the bank. Even though he sold most of the farmland, his wife took a job outside the farm business, and he himself worked some extra jobs, the inevitable could not be avoided - even though later on he wondered over and over if he could have taken another course. There was practically no other alternative left than to sell the farm, which was a joint personal decision of the couple, a fact that Kai also emphasized. After the commission of the estate agent had been deducted from the selling price, the cheque was taken directly to the bank. After this transaction, Kai (and the family) was still in considerable debt. The only positive outcome was that they avoided compulsory public auction of their farm, which would have made them kind of renegades or deserters in the eyes of the community.

After having given up the farm business and their dwelling place, they first took lodgings in the municipal centre of their original home district but soon took over the business that Kai's father handed over to him when retiring. There was a lot of work, and Kai did the best he could in order to pay for his previous loans until he became burnt out, was taken badly ill, and had to give up the business. It took him two years to recover. Kai’s illness (severe depression) was certainly precipitated by his desperate struggling for years with overwhelming economic difficulties, but it was launched by the circumstances in which his personal dignity, worthiness, and honour were at 
stake and even questioned in his home district - or what used to be his home district. The struggle for recognition is the most significant feature of the process during and after giving up that Kai experienced. Even though Kai and his family avoided public humiliation due to compulsory auction, which was their nightmare, they could not avoid the gossiping and malicious talk circulating in the small community. Such a 'communal spirit' often found expression in questions addressed to the family. Kai mentioned that:

The first year was spent in answering questions about why I have come back and why I left from there in the first place.

Kai constantly found himself obliged to explain and unveil to acquaintances and others what had really happened to the farm and why. It was easier to make Kai answer these questions since he was in a service business that he inherited from his father. For this reason, he also faced the question of 'why the son could run the service business only for 4-5 years when the father managed it 30 years'.

Although giving up the farm was for Kai a personal defeat and a cause of shame at first, he gradually realized that

I have come over it, and am no more ashamed, that it does not matter what others say. I make my life in this way and in a way ... not always of my own choice.

This happened only after Kai had recovered from his illness, thanks to the support of his family, and started to look for another job. In the meantime, during his leave of illness, he managed to get retraining. However, in the end he was lucky enough to be employed in the pig breeding business in 
his home district, where he could again realize his lifelong devotion to working with animals. Now he likes to look at his life, and the world, from this perspective too:

An animal is such, that ... in a way it is ... to be frank, when my head got really messed with all these twists, so the animal is always as it is. A dog knows nothing about the EU. It always behaves as it does.

These four stories (Tapio and Valma's, Jari’s, Markku's, and Kai's) are all unique, as are the other stories of persons who have given up farming. They do not compose a homogeneous group of people but a rather heterogeneous multitude. Some have managed the process very well indeed and can be truly satisfied with the outcome, while others have not fared as well, or at all. Naturally, their points of departure, economically and otherwise, were quite different. In addition, it must be emphasized that there are much more dramatic and painful experiences of giving up farming, genuine examples of social deprivation, which have not been taken up here even though some of these persons were also interviewed - although the most excluded persons are unavailable to interview since they have practically cancelled their 'social contract'. The reason for portraying these stories is that, although unique, they do not represent extreme cases but rather that which is quite common to precarization in agriculture.

\section{What is given up?}

The giving up of farming is seldom an overnight decision. The timing of this decision is significant since it reveals how well this process of quitting can be managed. In this process, time is a precious resource of decision and of desistance (Derrida, 1989) which can be used to postpone the decision. But the decision has to be made sooner or later. Abrupt decisions are often made in circumstances 
where there are absolutely no other alternatives available. Even if the giving up of farming has been made as a deliberate decision, since the 1990s, it has been made against the background of structural necessities and not just due to subjective reasons - although such subjectivities can reinforce the decision and play a crucial role, especially in cases of family-based difficulties.

The experiences of persons giving up farming reveal that there are especially three classes of structural reasons. The first reason is basically economic and relates to the consequences of global competition and crises, economic integration (EU), and economic concentration (Finland), which have made it quite impossible for small and medium-sized farms to continue their operation without truly substantial and risky economic investments for the future. The second, and corollary, reason is mainly political: both EU- and national agricultural policies and party politics in general have definitely followed a course emphasizing that only the biggest - that is, the most efficient and competitive agricultural units - can survive and deserve government support. The combined consequence of these structural causes is that the income of the small and medium-sized farms absolutely decreased in Finland since the early 1990s and made it plain to many, if not most, that giving up is the most viable option for the future.

Third, the rapid reduction in the number of agricultural units since the early 1990s due to the giving up of farming has taken place simultaneously with the restructuration of the welfare state regime in Finland. It is our conviction that the situations and experiences of those who have given up farming reveal uniquely the logic of the ongoing welfare state restructuration as well. The reason is not that those who have given up farming would have been a specific focus group of welfare state measures due to their strategic position. On the contrary, they have been quite totally neglected by the state as a specific group in turmoil. No special programs of recovery and re-employment have been tailored for the persons and their families who have given up farming. In their position they can, in 
principle, appeal to the measures of the welfare state that are accessible to all. They are like an unwritten sheet on which the traces of the newly restructured governmental measures can be recognized in the general matrix of citizenship, which is the domain of universalism. This is exactly why their experiences illustrate this governmental transformation especially with regard to the principal feature of the Nordic welfare regime, universalism.

The decision to give up farming has not been officially encouraged in public, since it could be looked upon silently as an absolutely necessary course of events that need not really be interfered with. In these circumstances, the farmers had to live through events of uncertainty and make their decisions behind the veil of ignorance. The fact of living with uncertainty and even anxiety is closely connected with the subjective factors behind giving up, as it truly challenges social and personal tranquillity. Since small- and middle-scale farming is not just a livelihood but a definite way of life, subjective factors always condition the course of action chosen, even if the decision to continue or give up relies on structural reasons. There are especially two classes of subjective reasons that are important as far as giving up is concerned. The first is made up of an assemblage of relations and connections of belongingness whose core is composed of the family, but that can extend to encompass social bonds and affiliations, drawing a zone for proximate action. Even though this zone certainly need not be characterized in terms of community, it does draw out a social context whose characteristic qualities can make understandable the exceptional misfortunes or fortunes among those individuals quitting farming.

The second class of subjective factors is rather directly connected with the personal devotion to agriculture as a life pattern, seen as a cultural continuity or tradition between generations (Silvasti, 2003a; 2003b). The 'giving up' can be seen as an apostasy, as discounting the true value of ancestral inheritance. On the other hand, the decision to give up farming was nourished by the 
media and other public opinion, which had been only too delighted to portray small- and middlescale agriculture as an obstacle to further modernization and progress, as a sign of backwardness.

The 'giving up' is often the outcome of a cumulative process in terms of precarization in which various factors, both objective and subjective, eventually join together to reach and exceed a threshold or a limit. Even if the individuals involved made the final decision of 'giving up', they usually do not have any or many means to crucially influence the course of events if they find themselves in a precarious position. In addition, it is a specific characteristic of this process that it takes place in a kind of official culture of indifference: no agency of government, no powerful public or private institution, no interest organization seems to be especially worried or topically interested in this process or its consequences. By treating it as a necessary and natural process of high-modernization and de-traditionalization, the authorities do not find any reason to take up the process of ‘giving up’ or its consequences on the political agenda.

Although the giving up of farming may sometimes turn out to be a blessing or a bliss for the person and the family concerned, even such a fortunate outcome cannot undo the fact that the decision to quit is basically an act of necessity, in the sense that one is here 'forced to be free'. Even if in most cases the decision could be temporarily postponed, there is a dynamic at work which, step by step, leads to the inevitable conclusion that the game cannot be continued by a player who has a losing hand. The giving up of the farm is a multi-dimensional decision. By quitting farming, one does not just give up a livelihood, but also leaves behind a life collective, a way of life, and a life-pattern. In the economic sense, the giving up of farming can naturally have an altogether different meaning for different persons and their families depending on their economic situation after having given up. However, the economic imperative, even though crucial or even decisive, is not the only relevant aspect of the process of giving up. 
The persons who give up their livelihood, the farming, become politically non-persons in the sense that their specific situation or their specific interests stemming from the (f)act of giving up no longer seem to strike any chord or find any topical response in the institutional setting of interest articulation and representation. After having given up, they have become politically precarious persons. They have gradually become ‘dead souls’ for their previous own organization, The Central Union of Agricultural Producers and Forest Owners (MTK), drifting into a kind of political 'no man’s land' that does not particularly interest any influential party or protagonist.

The structural turmoil in Finnish agriculture brought about by globalization, financialization, integration, and capital concentration did not come as a surprise to the farmers, even if the economic crisis of the early 1990s was a great shock. The early signs of the coming crisis were already in the air in the late 1980s, as for example Tapio and Valma’s story points out; but it was only in the 1990s that the farmers demonstrated collectively in public. The crucial reason for that was that Finland had started serious negotiations to join the EU, which culminated in early 1994. It was then, in late February 1994, that a couple of thousand farmers from Southern Finland quite spontaneously organized a demonstration in front of the EU embassy in Helsinki, tore down the EU flag, and dumped tons of snow on the street. The EU envoy Eric Hayes, who was present in the embassy, said smilingly that 'I have lived for years in Bryssels and seen demonstrations before. I must say that in comparison this demonstration is really peaceful and people behave correctly.'

The farmers' demonstration of 1994 was naturally nothing in comparison to what, for example, Jose Bové and his partners had notoriously organized in France (Bové and Dufour, 2001). This demonstration, and some other minor but similar protests, had little or no effect in that Finland joined the EU in 1995 in agreement with the leadership of both the Central Union of Agricultural 
Producers and Forest Owners, and the Centre Party of Finland. Against this background, it may seem somewhat paradoxical that in 1999 this Central Union had a major role in organizing a big farmers' demonstration to defend Finnish agriculture and food production in light of their rapidly deteriorating financial position. The rollicking, raucous, and impressive demonstration that evolved in front of Parliament even seemed to take the major organizers by surprise. The sight was spectacular, as demonstrators burned hay bales, carried heads of sheep on the tips of spears, dragged a pig carcass in front of the parliament, and publicly hanged a rag doll portraying the minister of agriculture and forestry responsible for Finland's EU-integration decision. All of these appearances were quite totally condemned and heavily criticized in public, especially by the forefront media such as Helsingin Sanomat, which had consistently championed Finland's decision to join the EU and had, for example, erroneously propagated that the price of foodstuffs would thereby be drastically reduced.

The farmers' demonstration of 1999 was a kind of epilogue to an irrevocable process that had already started a decade before; now, the consequences were already clearly in sight and had to be coped with, not only by those who had to give up farming but by all farmers in Finland. The polyphonic demonstration in itself made it clear that the course of events challenging Finnish farmers was characterized by a secondary social closure (Weber, 1976), since the farmers had to compete fiercely with each other for the fewer and fewer positions and stakes left behind for them by globalization and integration. The winners in this game have been the biggest players, and the losers have been those who had to give up, ending in precarious positions.

\section{From giving up to giving out}

The experiences of these persons giving up farming, like Tapio and Valma, Jari, Markku, and Kai, 
make clear that the decision to quit means giving up a way of life. They do not actually regret or even take note of a loss of community. Besides, there is a difference if a way of life or a definite way of life is given up. Those who have given up farming in Finland since the early 1990s comprise a small multitude. The question asked is not only why a definite way of life such as family farming is not possible and worthwhile in Finland, but why only a definite way of life such as living on profits or paid work - that is, a marketed existence - is possible. Their precarious experiences make one ask why is it that the autonomy of living 'how-so-ever' is constantly narrowing. This is a critical question that challenges the cultural myth of 'individualism' that is widely seen to characterize our globally integral market societies. The illusion of individualism naturally originates from the conviction that in making free choices in the market, people as producers, entrepreneurs, clients, customers behave individually according to their distinct preferences and styles. From another perspective, such behaviour might be seen as a sign of mass society. This perspective opens up if we try to learn something new about reading the process of giving up as precarization.

Persons who have given up farming have also given up a particular way of life that is no more institutionally complementary to or even compatible with the financial market economy, the present variety of capitalism. In their situation, these people are now compelled to cling to the modern entrepreneurial self and the ethos of market-oriented accountability. In order to regain their place in society, they have to find not only a new occupation (entrepreneur, employee), but also a more consumer-oriented way of life that is dependent on the services of others. A person who is autonomous and multi-skilled is not an ideal 'economic man' but rather one who is totally dependent on the services of others. This is another paradoxical reminder of the 'fallacy of individualism' that characterizes the dominant governmental ethos. Due to this neoliberal ethos of government, the welfare state also has to be fundamentally restructured. 
Throughout the restructuration of the welfare regime, people are not only constantly compared with each other but estimated, evaluated, classified, measured in order to be identified and recognized as proper objects of governmental measures. Persons - like those who have just given up farming who cannot be readily classified or easily located in pre-given government programs, policy scales and grades, action plans, official taxonomies and categories, administrative compartments, partnership schemes, are diverted into a kind of interzone where they are expected to transform themselves in order to better adapt to the globally dominant 'system-logic'. In all this restructuration of the welfare state in Finland, the stress is laid on the significance of freedom of choice, individual responsibility, and personal life-management as the key to success.

The process of giving up is such an all-encompassing experience that it penetrates every corner of the life-world of individuals. The earlier stories of giving up make clear that these processes address the structured opportunity to be recognized and not just livelihood or labour-market position as narrowly conceived. In this light, the struggle for recognition could be seen as the basic question of precarization. It is this subjective right for recognition and equality which is challenged by the 'logic of capital', as for example represented by the neoclassical 'microeconomics of life' (Becker, 1992). This 'managemental credo' exploits the argument that any person in the capitalist market society deserves what she gets, since that reward or punishment is due to the actual value of her time. When the precarious decision of giving up is understood in this matrix, it can be argued that these persons have to give up their occupation and way of life because their time is not valuable enough to continue as before. In this precarious situation, entrepreneurship is often offered as the most appropriate alternative available, even though it can easily lead out of the frying pan into the fire - as both Tapio/Valma’s and Kai’s stories illustrate.

As a process of precarization, giving up farming expresses sensitivity to initial conditions, which 
explains how it can start quite by chance and lead to insurmountable troubles. The aleatory character of the process expresses complex time-bindness. This explains why the persons involved have to constantly struggle with decisions of timing due to great uncertainty, un-foreseeability, and unpredictability of government policies and the double-bind in which the persons find themselves between lost past ideals and hidden future promises and expectations. This kind of 'despotism of the present' is quite oppressive and offensive for those living the paradoxical events of precarization, where individuals as personalities are downplayed by the power of empty abstractions which provide rules for capitalism as the game of games. But these situations of precarization can also offer alternative visions and social imaginaries to successfully bridge the past and the future in the common action mobilized by precarization. This would be a way from giving up to giving out - a politically creative solution.

\section{Bibliography}

Agrifood research Finland (2013) Finnish Agriculture and Rural Industries 2013 (Helsinki: MTT) https://portal.mtt.fi/portal/page/portal/mtt_en/mtt/publications/fari/jul114a_FA2013.pdf, date accessed 12. August 2014.

Agrifood research Finland (2014) Finnish Agriculture and Rural Industries 2014 (Helsinki: MTT) https://portal.mtt.fi/portal/page/portal/mtt_en/mtt/publications/fari/jul115a_FA2014.pdf, date accessed 20. March 2015.

Becker, G. S. (1992) ‘The Economic Way of Looking at Life’, Nobel Lecture, December 9, 1992, Economic Sciences, 38-58. http://www.nobelprize.org/nobel_prizes/economic- 
sciences/laureates/1992/becker-lecture.pdf, date accessed 13. March 2015.

J. Bové and F. Dufour (2001) The World is not for Sale. Farmers against Junk Food (London: Verso).

Derrida, J. (1989) ‘Introduction: Desistance’ in P. Lacoue-Labarthe Typography (Stanford, California: Stanford University Press).

Granberg, L. (1996) ‘Jäähyväiset sosiaaliselle politiikalle’, Maaseudun uusi aika 4, 64-68.

A. Honneth (1996) The Struggle for Recognition: The Moral Grammar of Social Conflict (Cambridge, Mass.: MIT Press).

Laitalainen, E., Silvasti, T. and Vesala, K. (2008) ‘Attributions and emotional well-being: giving up farming in Finland. Rural Society’, The Journal of Research into Rural Social Issues in Australia 18, 26-39.

A. Nygren, A (1936) Den Kristna Kärlekstanken Genom Tiderna: Eros och Agape (Stockholm: Svenska Kyrkans Diakonistyrelses Bokförlag).

S. Salamon (1992) Prairie Patrimony. Family, Farming \& Community in Mid-West (The University of North Carolina Press).

Silvasti, T. (2003a) 'The Cultural Model of "the Good Farmer” and the Environmental Question in Finland', Agriculture and Human Values 20, 143-150. 
Silvasti, T. (2003b) 'Bending Borders of Gendered Labour Division on Farms: the Case of Finland'. Sociologia Ruralis 43, 54-166.

M. Weber (1976) Wirtschaft und Gesellschaft. Tübingen: J.B.C. Mohr. 